Section Editor

Robert C. Griggs, MD
Editors' Note: Sethi and Bernat further discuss the advantages and problems concerning electronic health records $(E H R)$. Will we ultimately reach the ideal of having interoperability between different EHR software types? Rothman brings up the misconception that a response to methylphenidate in pediatric patients with different neurodevelopmental disorders is diagnostic of attention deficit disorder (ADD). This was not what Graf et al. discussed in their article relating to neuroenhancement in healthy subjects. Nonetheless, Graf et al. agree with Rothman and encourage the dissemination of information about the misuse and abuse of prescription stimulants.

—Chafic Karam, MD, and Robert C. Griggs, MD

\section{ETHICAL AND QUALITY PITFALLS IN ELECTRONIC HEALTH RECORDS}

Nitin K. Sethi, New York: Dr. Bernat should be commended for his article on the ethical and quality issues regarding EHR. ${ }^{1}$ The benefits are clear: history, preexisting problems, current medications, and other physicians' plans are accessible and evident in the electronic file. There are problems, however.

First, the physician must be in the same hospital system and using the same EHR. If the patient has consulted a physician outside the system, the patient's memory is the only aid in updating the medication list. Another downside is that it takes longer to complete and close the patient encounter. A 1-hour patient visit frequently becomes 1.5 hours because information must be entered. Some of my colleagues use templates to expedite the process but when others read the notes it is difficult to determine the decisionmaking process.

Dr. Bernat provides useful recommendations to mitigate some of the associated problems. I would add one more solution: EHR software should be compatible to allow transmission of information among physicians using different EHR systems without compromising patient confidentiality.

Author Response: James L. Bernat, Lebanon, NH: I thank Dr. Sethi for his thoughtful letter about my article. ${ }^{1}$ I agree that it would be desirable for all EHRs to be compatible as he suggests. This defect is only one of the
WriteClick: Editor's Choice

many shortcomings of commercially available EHRs. Although I only briefly mentioned it in my essay, I believe that there is no ideal EHR currently available, which is unfortunate given their enormous expense.

C) 2013 American Academy of Neurology

1. Bernat JL. Ethical and quality pitfalls in electronic health records. Neurology 2013;80:1057-1061.

\section{PEDIATRIC NEUROENHANCEMENT: ETHICAL, LEGAL, SOCIAL, AND NEURODEVELOPMENTAL IMPLICATIONS}

Steven M. Rothman, St. Louis: The recent article on pediatric neuroenhancement is an excellent review of the ethical aspects of stimulant drug use. ${ }^{1}$ However, the authors may be off point. Most children initially receive stimulant medications from general pediatricians and family physicians who believe that they are treating attention deficit disorder (ADD). These physicians do not believe that they are prescribing drugs for neuroenhancement. It is rare for children taking these drugs to have received psychometric testing and these drugs are frequently started in elementary school with initial success.

A large segment of the medical establishment still believes that a positive response to stimulants is diagnostic of $\mathrm{ADD}$, so this success is viewed as a validation of the diagnosis. After several years, when the drugs begin to fail, children are referred for a dose adjustment-or a new drug. At that point, a previously ignored learning disability is often identified. In pediatric neurology, we would do better by educating our colleagues in primary care that stimulant medications initially help almost every child do better in school, at the price of neglecting many important learning disabilities that merit early attention. If Graf et al. provoke us to do this, they will have provided an invaluable service to hundreds of thousands of children.

Author Response: William D. Graf, New Haven, CT; Saskia K. Nagel, Osnabruck, Germany; Leon G. Epstein, Chicago; Geoffrey Miller, New Haven, CT; Dan Larriviere, New Orleans: In our recent ethics position paper, we defined neuroenhancement as "the use of prescription medication by healthy persons for the purpose of augmenting normal cognitive or affective function." ${ }^{1}$ Thus, neuroenhancement should not be confused with the potential beneficial effects of 
medication in neurologic disorders such as attentiondeficit/hyperactivity disorder (ADHD).

Dr. Rothman's comments relate to the indiscriminate use of prescription stimulants for children with other neurodevelopmental disorders such as specific learning disabilities and vaguely defined conditions such as central auditory processing disorder. In these disorders, signs of ADHD_including inattentiveness, impulsivity, and hyperkinesis - may coexist. ${ }^{2}$ Stimulants may show some benefit in these multidimensional disorders. ${ }^{3,4}$

Separate questions relate to diagnostic accuracy and whether any neurologic disorder exists at all. We agree with Dr. Rothman about the common misperception that "Ritalin-responsiveness" justifies an ADHD diagnosis. We are also generally concerned about the significant increase in the use of prescription stimulants and the possible overdiagnosis of ADHD. Nonmedical use of methylphenidate and amphetamines and the illicit diversion of these drugs to healthy students for neuroenhancement may account for some of the recent rise in ADHD diagnoses.
Public dissemination of information about the misuse and abuse of prescription stimulants is necessary. ${ }^{5}$

(C) 2013 American Academy of Neurology

1. Graf WD, Nagel SK, Epstein LG, Miller G, Nass R, Larriviere D. Pediatric neuroenhancement: ethical, legal, social, and neurodevelopmental implications. Neurology 2013;80: 1251-1260.

2. Pastor PN, Reuben CA. Diagnosed attention deficit hyperactivity disorder and learning disability: United States, 2004-2006. Vital Health Stat 10 2008;237:1-14.

3. Shafritz KM, Marchione KE, Gore JC, Shaywitz SE, Shaywitz BA. The effects of methylphenidate on neural systems of attention in attention deficit hyperactivity disorder. Am J Psychiatry 2004;161:1990-1997.

4. Tillery KL, Katz J, Keller WD. Effects of methylphenidate (Ritalin) on auditory performance in children with attention and auditory processing disorders. J Speech Lang Hear Res 2000;43:893-901.

5. International Narcotics Control Board (INCB). Report of the International Narcotics Control Board for 2012. Vienna: United Nations; 2013.

\section{Neurology ${ }^{\circledR}$ WriteClick: Join the Debate!}

The editors encourage comments about recent articles through WriteClick:

Go to www.neurology.org and click on the "WriteClick" tab at the top of the page. Responses will be posted within 72 hours of submission.

Before using WriteClick, remember the following:

- WriteClick is restricted to comments about studies published in Neurology within the last eight weeks

- Read previously posted comments; redundant comments will not be posted

- Your submission must be 200 words or less and have a maximum of five references; reference one must be the article on which you are commenting

- You can include a maximum of five authors (including yourself) 


\title{
Neurology
}

\author{
Pediatric neuroenhancement: Ethical, legal, social, and neurodevelopmental \\ implications \\ Steven M. Rothman, William D. Graf, Saskia K. Nagel, et al. \\ Neurology 2013;81;1558-1559 \\ DOI 10.1212/01.wnl.0000437277.02794.3a
}

This information is current as of October 21, 2013

\section{Updated Information \& Services}

References

Permissions \& Licensing

Reprints including high resolution figures, can be found at: http://n.neurology.org/content/81/17/1558.2.full

This article cites 4 articles, 1 of which you can access for free at: http://n.neurology.org/content/81/17/1558.2.full\#ref-list-1

Information about reproducing this article in parts (figures,tables) or in its entirety can be found online at:

http://www.neurology.org/about/about_the_journal\#permissions

Information about ordering reprints can be found online:

http://n.neurology.org/subscribers/advertise

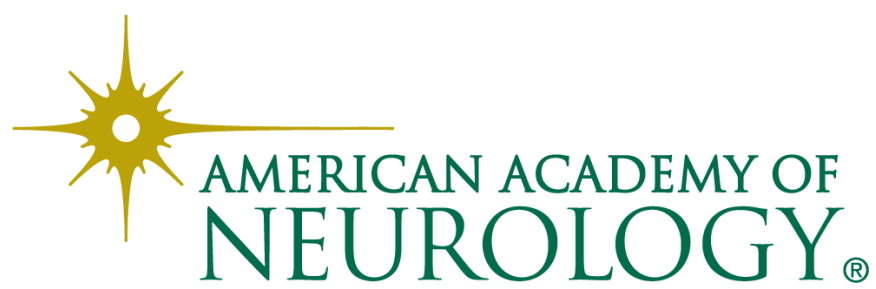

